\title{
Plastic Waste Management by Substituting Natural Fibres
}

\author{
Surabhi Srivastava \\ Department of Civil Engineering, Bahra University, Shimla Hills, Himachal Pradesh, India. \\ Email: surabhi0065@gmail.com
}

Received December 31 ${ }^{\text {st }}$ 2011; revised February $1^{\text {st }}$, 2012; accepted February $11^{\text {th }}$, 2012

\begin{abstract}
This paper presents substitute for non-biodegradable plastic packed material which comes as a part of municipal solid waste and becoming global problem due to its overuse. The plastic as packaging material has its advantages but also have more disadvantages because of its durability that it does not degraded. If the packaging material is made up of natural fibres it has more effect on local ecosystem. This paper provides the solution that use of natural fibres as packaging due to its light weight, high strength to weight ratio, corrosion resistance and other advantages are useful for the industry as well as commercially availability for the markets.
\end{abstract}

Keywords: Solid Waste; Biodegradable; Non-Biodegradable; Plastic; Natural Fibres

\section{Introduction}

In developing countries of the world, plastic waste has become a current challenge for the environmental engineers to solve. For an example developing country like India, statistics show that the exponential growth rate of India with $1,210,000,000$ (1.21 billion) people is the second most populous country in the world, while China is on the top with over 1,350,044,605 (1.35 billion) people. The figures show that India represents almost $17.31 \%$ of the world's population, which means one out of six people on this planet live in India. Although, the crown of the world's most populous country is on China's head for decades, India is all set to take the numerous positions by 2030. With the population growth rate at $1.58 \%$, India is predicted to have more than 1.53 billion people by the end of 2030. Being second most populous country in the world, India continuously keeps on adding waste material within its geographical boundaries. India has about $16 \%$ of the world population and $2.5 \%$ of world's land area. In an already densely populated country with even more densely packed urban centers, land for proper waste treatment, disposal and overall management is scarce. Recent and sustained economic growth increasing living standards of the people, increased manufacturing and production activities has led to increased to rapid rise in the waste generation rated [1]. India produces around 42 Million tons of solid waste annually. There is wide difference in the waste generation rates in rural and urban areas. Even within the urban areas, the composition includes more paper and inert material and less of organic and compostable material as the city population and size increases. The per capita gen- eration rate increases and the overall calorific value of the waste drops with increase in the size of the city (Study by NEERI).

Now with the above data we can calculate the per day generation of solid waste of India \& also we can calculate the expected cost for its management which can be done by the processes minimization, recycling \& disposal of the solid waste generated. These processes have been adopted by the most developed countries as the menu for developing solid waste management strategies $[2,3]$. Depending upon a number of factors such as topography climate [4], population density (village to metro city), transportation infrastructure, socioeconomic and environmental laws of India it is important to make proper pre action plan to manage solid waste.

\section{Composition of Municipal Solid Waste in India}

The biodegradable portion dominates the bulk of $\mathrm{Mu}-$ nicipal Solid Waste. Generally the biodegradable portion is mainly due to food and yard waste. With rising urbanization and change in lifestyle and food habits, the amount of municipal solid waste has been increasing rapidly and its composition changing. Figure 1 represents Pie chart for the various category of waste generated. There are different categories of waste generated, each take their own time to degenerate (as illustrated in the Table 1 [5]).

\section{Method of Data Collection}

There is a manual method of data collection [6,7], which will be important while designing a tool or waste treatment 
Table 1. The type of litter we generated \& the approximate time it takes to degenerate.

\begin{tabular}{|c|c|}
\hline Type of Litter & Approximate time to degenerate the litter \\
\hline Vegetable, fruitpeel, leaves, foodstuffs & A week or two \\
\hline Paper & 10 - 30 days \\
\hline Cotton cloth & 2 - 5 months \\
\hline Wood & $10-15$ years \\
\hline Woolen items & 1 year \\
\hline Tin, aluminium and other metal items such as cans & 100 - 500 years \\
\hline Glass bottles & Undetermined \\
\hline
\end{tabular}

Source: NSWAI-National Solid Waste Association of India.

Table 2. Per capita waste generation in India cities.

\begin{tabular}{cc}
\hline Population range (million) & Average per capita waste generation (gm/capita/day) \\
\hline $0.1-0.5$ & 210 \\
$0.5-1.0$ & 250 \\
$1-2$ & 230 \\
5 and above & 500 \\
\hline
\end{tabular}

Source: National Environmental Engineering Research Institute, India, 1995.

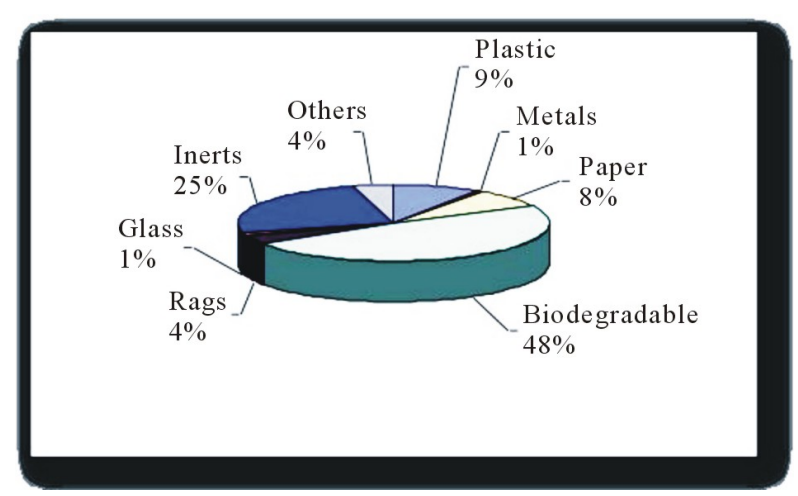

Figure 1. Pie chart presentation of various category of waste generated.

plant in future period. The future period for which a provision is made in the waste management scheme is known as the design period for the waste management system. It is necessary to estimate this future population as accurately as possible. Depending upon the possibilities of the future development of the country \& its increasing population will definitely emit the plastic waste on large scale. Then the plastic waste management tools will be designed on the possible future population of the region, .The population growth rate at $1.58 \%$, India is predicted to have more than 1.53 billion people by the end of 2030 by the Geometric Increase Method of population forecasting. According to CPCB waste generated by per person per day 490 gms. It is estimated that upto 2030 the waste generated by per person per day will be 750 gms. Simply by multiplying we can calculate the waste generated by more than 1.53 billion people by the end of 2030.

Other sources of information include personal observation, news reports, books \&journals. Field surveys were carried out in some areas \& the active official dumpsites on the various samples of waste generated were collected.

\section{Result and Discussions}

Table 2 gives data on per capita waste generation in Indian cities out of which the $50 \%$ of waste is plastic waste. Technically, we use plastics for packaging material, may be defined as a material that contains a polymerized organic substance of large molecular weight. We can use Natural fiber as packaging material instead of plastic due to its properties like-light weight, high strength to weight ratio, low cost \& availability [8]. However, natural fiber based packaging materials are environment friendly to a large extent.

\section{Conclusion}

The investment for an on-site waste management system in an individual health care setting is very high. In contrast, an integrated common treatment \& disposal facility 
cost a maximum of Rs. 3 to $15 / \mathrm{kg} /$ day with an added benefit of no capital investment being required. The company could have profit about 35\% making it a sustainable venture if they use natural fibres as packaging material instead of plastic [4]. The natural fibres are environmentally sound it will also give good market cost to the farmers

\section{REFERENCES}

[1] F. Ackerman, "Waste Management and Climate Change," Local Environment, Vol. 5, No. 2, 2000, pp. 223-229. doi:10.1080/13549830050009373

[2] N. Berge, D. Reinhart and T. Townsend, "A Review of the Fate of Nitrogen in Bioreactor Landfills," Critical Reviews in Environmental Science and Technology, Vol. 35, No. 4, 2005, pp. 365-399. doi:10.1080/10643380590945003

[3] B. Bockreis and I. Steinberg, "Influence of MechanicalBiological Waste Pre-Treatment Methods on Gas Formation in Landfills," Waste Management, Vol. 25, No. 4, 2005, pp. 337-343. doi:10.1016/j.wasman.2005.02.004
[4] D. De Jager and K. Blok, "Cost-Effectiveness of Emission-Reduction Measures for CH4 in the Netherlands," Energy Conservation Management, Vol. 37, No. 6-8, 1996, pp. 1181-1186. doi:10.1016/0196-8904(95)00317-7

[5] L. F. Diaz, A. Chiumenti, G. Savage and L. Eggerth, "Managing the Organic Fraction of Municipal Solid Waste," Biocycle, Vol. 47, No. 10, 2006, pp. 50-53.

[6] R. R. Jenkins, S. A. Martinez, K. Palmer and M. J. Podolsky, "The Determinants of Household Recycling: A Material-Specific Analysis of Recycling Program Features and Unit Pricing," Journal of Environmental Economics and Management, Vol. 45, No. 2, 2003, pp. 294-318. doi:10.1016/S0095-0696(02)00054-2

[7] Swedish Environmental Protection Agency, “A Strategy for Sustainable Waste Management: Sweden's Waste Plan,” Swedish Environmental Protection Agency, Stockholm, 2005, p. 54

[8] US Environmental Protection Agency, "Municipal Solid Waste Generation, Recycling and Disposal in the United States: Facts and Figures for 2003,” US Environmental Protection Agency, Washington DC, 2005. 